ISSN : 2356-4164

\title{
PARADIGMA DALAM POLA PEMIDANAAN (DARI MODEL PENGHUKUMAN FISIK KE MODEL PEMBINAAN PSIKIS)
}

\author{
Nazifah \\ Fakultas Hukum \\ Universitas Batanghari Jambi \\ E-mail : nazifahthojib@gmail.com
}

\begin{abstract}
ABSTRAK
Keseimbangan antara nilai kepastian hukum dan ketertiban sosial harus segera diwujudkan dalam suatu perubahan paradigma baru. Hukum diciptakan bukan untuk memberikan penderitaan pada manusia, melainkan diciptakan untuk kebaikan/ kemaslahatan umat manusia. Pemikiran kaum abolisionis dapat dijadikan dasar perubahan paradigma dalam pemberian sanksi pidana/sistem pemidanaan, dari model pemidanaan yang bersifat fisik menuju kepada model pemidanaan yang bersifat psikis. Hal ini dirasakan perlu mengingat kurang mampunya model pemidanaan yang bersifat fisik memberikan nilai keadilan. Berkaitan dengan model pemidanaan dari yang bersifat fisik menuju model pemidanaan yang bersifat psikis ini, maka yang pertama harus dilakukan adalah perubahan model sistem peradilan pidana dari yang bersifat retributive justice ke arah peradilan yang bersifat restorative justice.
\end{abstract}

Kata kunci: Sistem peradilan pidana.

\section{ABSTRACT}

Balance between the value of the rule of law and social order should be embodied in a new paradigm shift. Law was created not to provide the human suffering, but was created for the good / benefit of mankind. The abolitionist thought can be used as the basis of a new paradigm shift in the delivery of criminal sanctions / punishment system, on the model of a physical punishment leads to models that are psychic punishment. This is necessary given the unqualified conviction that physical models give justice. Related to the model of the physical punishment toward a model that is both psychic punishment, then the first thing to do is change the model of a criminal justice system from retributive justice to restorative justice.

Keyword: criminal justice system

\section{Pendahuluan}

Manusia adalah homo sapiens

(makhluk yang berpikir) yang mencerminkan kaitan antara pengetahuan yang bersifat teoritis dengan teknologi yang bersifat praktis. Berbeda dengan seni yang bersifat estetis, maka ilmu adalah pengetahuan yang dikembangkan oleh manusia untuk memecahkan masalahmasalah praktis dalam kehidupannya (Jujun S.Suriasumantri,2003:161). Begitu juga manusia untuk mencapai ketertiban dalam kehidupan 
bermasyarakat perlu adanya aturan hukum.

Fungsi hukum sendiri menurut Mochtar Kusumaatmadja (2006:14), merupakan suatu alat untuk memelihara ketertiban dalam masyarakat. Mengingat fungsinya, sifat hukum pada dasarnya adalah konservatif. Artinya hukum bersifat memelihara dan mempertahankan yang telah dicapai. Fungsi demikian diperlukan dalam setiap masyarakat, termasuk masyarakat yang sedang membangun, karena disini pun ada hasil-hasil yang harus dipelihara, dilindungi, dan diamankan. Tetapi masyarakat yang sedang membangun, yang dalam arti masyarakat yang berubah cepat, hukum tidak dapat memiliki fungsi yang demikian saja, hukum harus dapat membantu proses perubahan masyarakat itu sendiri.

Hukum memberikan seni dan kreativitas pada manusia, sehingga hukum terlihat mempunyai fungsi yang multi dimensional terhadap manusia, misalnya hukum dapat berfungsi sebagai alat rekayasa sosial (tools of social engineering) yang merupakan salah satu aspek pengubah sosial (Sudjono Dirdjosiswono,1996:77).

Hukum sebagai suatu aspek pengubah tentunya dapat menjadi suatu instrumen yang kuat untuk dijalankan oleh anggota masyarakat karena di dalamnya termuat nilai-nilai kesepakatan dari masyarakat sebagai keinginan bersama dan nilai-nilai kebebasan dari anggota masyarakat dalam rangka memberikan keseimbangan. Suatu bangunan hukum dikatakan berdiri tegap dan baik tentunya berada di atas struktur pondasi yang seimbang, kerangka yang seimbang, dinding yang seimbang dan atap yang seimbang. Ketika salah satu aspek bangunan itu tidak seimbang, maka akan terjadi kemiringan dan memiliki efek negatif, misalnya ketidaknyamanan, bahaya tinggi dan bahkan kehancuran. Oleh karenanya, apabila terjadi bangunan hukum sebagaimana tergambar dalam sketsa di atas, maka perlu segera dilakukan perubahan atau perbaikan (reform) demi memberikan keseimbangan atau dengan kata lain memberikan keadilan baik terhadap masyarakat secara keseluruhan maupun terhadap individual sebagai anggota masyarakat. Perubahan terhadap bangunan hukum pada dasarnya harus dilihat secara komprehensif dan multi-dimensional, karena keserasian atau keseimbangan atau keindahan hukum sebagai suatu seni tidak dapat dilihat pada satu sisi saja. Kemiringan suatu bangunan juga ditentukan oleh pondasi dan tiangtiang bangunan.

Sebagai suatu negara hukum yang mempunyai landasan filosofi (groundnorm) yang kuat, sudah selayaknya Indonesia melakukan perubahan-perubahan hukum secara komprehensif dan multi-dimensional yang didasarkan pada nilai-nilai kebersamaan demi mencapai tujuan akhir yang dicita-citakan oleh setiap negara hukum, yaitu walfare state (negara sejahtera).

Bertitik tolak dari pentingnya menjaga keseimbangan antara nilainilai individu dan nilai-nilai kemasyarakatan, maka perlu dilakukan perubahan-perubahan sosial. Salah satu perubahan yang penting dalam kehidupan manusia adalah perubahan terhadap hukum. 
Berkaitan dengan masalah perlindungan sosial, salah satu masalah sosial yang marak muncul akhir-akhir ini adalah mengenai perkembangan kejahatan, sehingga menuntut ranah hukum kriminal (criminal law) untuk bekerja lebih keras dalam menanggulanginya. Usaha-usaha penanggulangan kejahatan telah dilakukan dengan berbagai cara, namun hasilnya belum memuaskan, bahkan kejahatan tetap terus berjalan seperti fenomena yang tiada putusnya.

Pandangan di atas menunjukkan bahwa masalah penanggulangan kejahatan dengan menggunakan pidana merupakan suatu problem sosial yang terus-menerus terjadi. Hal ini terlihat pula dari apa yang dikatakan oleh Herbert L. Packer: "usaha pengendalian perbuatan anti sosial dengan mengenakan pidana pada seseorang yang bersalah melanggar peraturan pidana merupakan suatu problem sosial yang mempunyai dimensi hukum yang penting" (Barda Nawawi Arief, 1996:16-17). Namun penulis berpandangan bahwa kejahatan merupakan fenomena sosial yang sulit untuk ditanggulangi dengan menggunakan sarana penal (pidana) yang bersifat konvensional, artinya selama ini kebijakan penggunaan sanksi pidana secara monolistik, sementara kejahatan terjadi bukan hanya disebabkan perilaku yang bebas saja dari pelakunya (independen), tetapi jauh lebih besar disebabkan oleh faktor luar dari diri pelaku (dependen) yang mempengaruhi psikologisnya.

Sebagai suatu usaha yang rasional dalam rangka mencapai kesejahteraan masyarakat, penggunaan sanksi pidana sebenarnya bukan merupakan sesuatu keharusan yang mutlak, karena pada hakikatnya dalam masalah kebijakan orang berhadapan pada penilaian dan pemilihan dari berbagai alternatif (Sudarto,1977:161), dengan demikian masalah pengendalian kejahatan dengan menggunakan sanksi pidana bukan hanya merupakan masalah sosial seperti yang dikemukakan oleh Herbert L. Packer di atas, melainkan juga merupakan masalah kebijakan (the problem of policy).

Memang benar, bahwa kejahatan atau tindak pidana merupakan salah satu bentuk dari perilaku menyimpang yang fenomenal yang selalu melekat pada tiap bentuk masyarakat, namun patut disadari pula bahwa perilaku menyimpang itu merupakan ancaman yang nyata terhadap norma-norma sosial yang mendasari kehidupan dan keteraturan sosial (Saparinah Sadli,1976:56). Keteraturan sosial merupakan bagian dari kesejahteraan sosial sangat mustahil untuk dicapai hanya dengan sebatas penggunaan sanksi pidana. Lambat laun penggunaan sanksi pidana diragukan kemampuannya dalam menanggulangi kejahatan, hal ini terbukti dari munculnya pemikirpemikir abolisionis untuk menggantikan sanksi pidana dengan hukum perlindungan sosial.

Para pemikir abolisionis mempermasalahkan penggunaan sanksi pidana dalam menanggulangi kejahatan dengan mengatakan "pidana merupakan peninggalan dari kebiadaban kita masa lalu (a vestige of our savage past) yang seharusnya dihindari (Barda Nawawi Arief, 
1996:18). Kemudian atas dasar kebiadaban itu ada pendapat yang mengatakan bahwa teori retributif (pembalasan) dalam hal pemidanaan merupakan a relic of barbarism.

Pemikiran kaum abolisionis ini dapat dijadikan dasar perubahan paradigma dalam pemberian sanksi pidana/sistem pemidanaan, dari model pemidanaan yang bersifat fisik menuju kepada model pemidanaan yang bersifat psikis. Hal ini dirasakan perlu mengingat kurang mampunya model pemidanaan yang bersifat fisik memberikan nilai keadilan bahkan menjurus pada cara-cara barbarism yang jauh dari nilai kemanusiaan. Berdasarkan latar belakang masalah di atas, maka diperlukan suatu lompatan paradigma dalam pola pemidanaan bagi para pelaku kejahatan dengan harapan dapat memberikan keseimbangan hukum yang bermuara pada tegaknya nilai keadilan dan ketertiban. Oleh karenanya rumusan masalah dalam tulisan ini adalah: "mengapa model penghukuman fisik perlu diubah dengan model pembinaan psikis dalam sistem pemidanaan?".

\section{Metode Penelitian}

Dalam pengumpulan data/bahan untuk penulisan karya ilmiah dalam bentuk makalah ini, maka digunakan metode penelitian, yaitu penelitian kepustakaan (library research).

Sumber data yang digunakan adalah sumber data sekunder, yaitu, suatu data yang diperoleh dari hasil penelitian terhadap buku-buku atau literatur lainnya yang memiliki hubungan dengan objek penelitian (Soerjono Soekanto,1986:12). Objek penelitiannya berupa penelitian terhadap peraturan perundangundangan dan peraturan lainnya mengenai filsafat ilmu dan paradigma dalam pola penghukuman dari model fisik ke model pembinaan psikis.

\section{Pembahasan}

Sebelum penulis membahas tentang sistem pemidanaan, ada baiknya penulis singgung sedikit mengenai paradigma. Paradigma menurut Thomas Kuhn adalah suatu penempatan kerangka/cara/metode berfikir berdasarkan keilmuan yang dapat dibuktikan kebenarannya. Paradigma berfungsi sebagai framework bagi ilmuwan (pemikir) dalam suatu pengkajian atau penelitian bidang tertentu yang didasarkan pada keyakinan, komitmen dan konsistensi (focus).

Perubahan suatu paradigma dapat saja terjadi dalam waktu-waktu tertentu, (dapat terjadi dalam waktu yang singkat atau dalam waktu yang sangat lama). Sepanjang belum ada atau belum muncul pola berfikir yang baru, maka paradigma yang lama tentang suatu keilmuan akan bertahan Demikian pula halnya dalam perkembangan keilmuan sistem pemidanaan yang ada, mungkin saja dalam keilmuan ini diperlukan lompatan paradigma, karena paradigma lama dirasakan tidak mampu lagi memberikan nilai keadilan, memenuhi hasrat kebutuhan hukum pidana atau memenuhi tujuan hukum pidana itu sendiri, yaitu memberikan keadilan dan ketertiban di tengah masyarakat tertentu.

\section{Perkembangan Sistem Pemidanaan} Perkembangan sistem pemidanaan itu sendiri sebenarnya 
tidak lepas dari perkembangan model peradilan pidana yang ada di dunia, dan model peradilan pidana itu dipengaruhi oleh sistem hukum yang dianut oleh negara pelaksananya masing-masing. Idealnya model peradilan pidana beserta dengan sistem sanksinya tersebut harus sesuai dengan ideologi Negara tersebut.

Sedangkan Muladi (1995:1-2) mengatakan sistem peradilan pidana merupakan suatu jaringan (network) peradilan yang menggunakan hukum pidana materiel, hukum pidana formil maupun hukum pelaksanaan pidana. Namun kelembagaan ini harus dilihat dalam konteks sosial, karena sifat yang terlalu formal jika dilandasi hanya untuk kepentingan kepastian hukum saja akan membawa bencana berupa ketidakadilan.

Sementara itu Mardjono Reksodiputro (1997:84) memberikan batasan tentang sistem peradilan pidana, yaitu sebagai suatu sistem pengendalian kejahatan yang terdiri dari lembaga-lembaga kepolisian, kejaksaan, pengadilan dan pemasyarakatan terpidana. Menilik dari pandangan tersebut, Romli Atmasasmita berpendapat bahwa:

(1996:15-16)

pengertian sistem peradilan pidana dalam batasan seperti itu merupakan bahasa manajemen yang berarti mengendalikan atau menguasai atau melakukan pengekangan dalam menanggulangi kejahatan, sedangkan apabila sistem peradilan pidana diartikan sebagai suatu penegakan hukum, maka di dalamnya terkandung aspek aspek hukum yang menitikberatkan kepada operasionalisasi peraturan perundng- undangan dalam upaya menanggulangi kejahatan dan bertujuan untuk mencapai kepastian hukum (certainty). Di lain pihak apabila pengertian sistem peradilan pidana dipandang dari sebagai bagian dari pelaksanaan social defence yang terkait kepada tujuan mewujudkan kesejahteraan masyarakat, maka dalam sistem peradilan pidana terkandung aspek sosial yang menitik beratkan kegunaan (expediency).

Berdasarkan pandanganpandangan tersebut di atas, kiranya dalam mengenal sistem peradilan pidana dapat dilakukan tiga pendekatan, sebagaimana yang dikatakan oleh Geoffrey Hazard (Dalam Romli Atmasasmita, 1996:17) yaitu:

a. Pendekatan Normatif yang memandang keempat aparatur penegak hukum sebagai institusi pelaksanaan peraturan perundangundangan yang berlaku, sehingga keempat aparatur tersebut merupakan bagian yang tidak terpisahkan dari sistem penegakan hukum semata-mata;

b. Pendekatan administratif yang memandang keempat aparatur penegak hukum sebagai suatu organisasi manajemen yang memiliki mekanisme kerja, baik hubungan yang bersifat horizontal maupun yang bersifat vertikal sesuai dengan struktural organisasi yang berlaku dalam organisasi tersebut, sistem yang digunakan adalah sistem administratif.

c. Pendekatan sosial yang memandang keempat aparatur penegak hukum merupakan bagian yang tak terpisahkan dari suatu sistem sosial, sehingga masyarakat 
secara keseluruhan ikut bertanggung jawab atas keberhasilan atau ketidakberhasilan dari keempat aparatur penegak hukum tersebut dalam melaksanakan tugasnya. Sistem yang dipergunakan adalah sistem sosial.

\begin{tabular}{lll}
\multicolumn{2}{c}{ Bagaimana dengan sistem } \\
peradilan pidana yang dianut
\end{tabular} Indonesia? Berbicara mengenai model peradilan pidana yang dilaksanakan di Indonesia berarti berbicara juga tentang hukum acara pidana dan penegakannya. Sebagaimana telah penulis sampaikan secara singkat pada bagian di atas, hukum acara pidana sebagaimana yang diatur dalam KUHAP pada dasarnya menganut due process law model namun penegakannya masih sangat kental dengan crime control model.

Dalam beberapa praktek penegakan hukum pidana umum, crime control model dapat dilihat pada jenis tindak pidana konvensional yang dilakukan oleh pelaku warungan/warga marjinal. Kecepatan dengan alasan efisiensi dalam rangka mengejar criminal rate sangat diutamakan, sehingga meninggalkan perlindungan hak-hak tersangka atau terdakwa. Contohnya beberapa kasus pencurian dengan tingkat kerugian kecil, seperti pencurian semangka, pencurian biji coklat, pencurian piring dan lainnya sangat cepat diselesaikan dengan cara-cara represif. Para pelaku dianggap musuh masyarakat dan tidak pernah dilakukan upaya penyelesaian dengan alternatif lain, karena crime control model memang menganggap seluruh tindak pidana tanpa kecuali harus dihadapkan kepada pengadilan untuk mendapatkan keputusan hakim.
Efisiensi dalam model ini dimaknai sebagai penghematan prosedural tanpa memikirkan hasil atau kemanfaatan dari tindakan yang dilakukan. Korelasinya adalah memunculkan tindakan represif dan bersifat konservatif. Acuan penegakan hukum seperti ini adalah retributive justice (peradilan pembalasan).

Selain dari itu, sistem peradilan pidana di Indonesia tidak dilakukan secara konsekuen dengan substansi pengaturan yang terdapat di dalam hukum pidana formilnya (KUHAP) yang jelas-jelas memberi perlindungan kuat terhadap hak asasi manusia dalam satu rangkaian prosedural yang telah diatur dalam perundang-undangan, yang merupakan ciri dari model due process law.

Memperhatikan pandangan Hazard yang dihubungkan dengan pelaksanaan penegakan hukum di Indonesia, maka kita dapat mengatakan bahwa sistem peradilan pidana yang dilaksanakan di Indonesia masih berkutat dengan pendekatan normatif, karena seluruh rangkaian penegakan hukum dilakukan dalam rangka menjalankan peraturan perundang-undangan, baik yang dilakukan oleh polisi, jaksa, pengadilan dan lembaga pemasyarakatan. Kalaupun ada kaitan dengan pelaksanaan manajemen peradilan itupun hanya pemenuhan administratif yang telah diatur dalam perundang-undangan.

Dengan model peradilan yang demikian, maka sudah barang tentu sistem sanksi yang diberikan kepada pelaku tindak pidana didasarkan pada pola-pola pemenuhan adminstrasibirokrasi, paradigma seperti ini sangat 
memungkinkan terjadinya penyimpangan administrasi dalam pelaksanaan birokrasi organisasi peradilan pidana. Demikian pula sanksi-sanksi yang dijatuhkan (yang berupa fisik) akan sangat tidak efektif dan tidak efisien.

Dalam sejarah perkembangan pemidanaan ada beberapa teori yang dikenal dalam sistem peradilan pidana, misalkan saja vergeldings theorien (teori pembalasan), doel theorien (teori tujuan) dan verenigings theorien (teori gabungan).

Teori pemidanaan yang pertama kali muncul adalah Vergeldings Theorien (teori pembalasan) sering pula disebut dengan absolute theory atau dikenal juga dengan istilah retributive theory tumbuh dan berkembang pada zaman klasik yang menerapkan sistem hukum yang dibuat oleh Raja secara langsung.

Dalam perkembangan selanjutnya, teori ini memunculkan reaksi keras dari filosof Aristoteles. Aristoteles (dalam W. Friedmann,1996:10) memunculkan theory ethisce (teori keadilan) yang menekankan hukum hanya bertujuan memberikan keadilan (justice), dan keadilan menurut beliau dibagi menjadi dua bagian, yaitu keadilan distributif (distributief justice) dan keadilan korektif (corectief justice).

Keadilan distributif mengacu pada pembagian barang dan jasa kepada setiap orang sesuai dengan kedudukannya dalam masyarakat, dan perlakuan yang sama terhadap kesederajatan dalam hukum (equality before the law). Keadilan jenis ini menitikberatkan pada kenyataan fundamental yang sangat mendasar meskipun banyak dikesampingkan oleh para filosof hukum lain dalam mempertahankan teorinya.

Keadilan korektif pada dasarnya merupakan ukuran teknis dari prinsip-prinsip yang mengatur penerapan hukum. Dalam mengatur hubungan-hubungan hukum harus ditemukan suatu standar yang umum untuk memperbaiki setiap akibat dari setiap tindakan, tanpa memperhatikan pelakunya, dan tujuan dari perilakuperilaku serta objek-objek harus diukur melalui suatu ukuran yang objektif. Hukuman harus memperbaiki kejahatan, ganti rugi harus memperbaiki kerugian masyarakat dan memulihkan keuntungan yang tidak sah.

Teori keadilan dari Aristoteles ini berkembang menjadi teori tujuan (utilitarian theory) yang dalam sistem pemidanaan dikenal dengan Doel Theorien atau sering pula dikenal dengan teori relativitas. Dalam teori ini tujuan pemidanaan adalah memberikan rasa jera pada pelaku (special prevention) dan menakutnakuti masyarakat agar tidak mengikuti perilaku tersebut (general prevention).

Dalam perjalanannya, banyak negara di dunia menggunakan teori ini, termasuk di Indonesia dengan sistem kepenjaraan yang merupakan hasil dari sistem pemidanaan Eropa Kontinental yang dipakai Belanda (berdasarkan asas konkordansi) sampai akhirnya diubah menjadi sistem pemasyarakatan pada tahun 1982. Sistem pemasyarakatan yang dikenal di Indonesia saat ini adalah bagian dari perkembangan pemikiran filosof yang beraliran sociological Jurisprudence (al: Roscoe Pound, Eugene Ehrlich, dll) yang menekankan 
bahwa hukum yang baik adalah hukum yang sesuai dengan hukum yang hidup dalam masyarakat (Zainuddin Ali,2009:60). Aliran ini kemudian memunculkan teori social engineering Dirdjosisworo,1996:77) yang menekankan bahwa hukum adalah alat rekayasa sosial yang pada dasarnya konstruksi hukum itu berasal dari nilai-nilai yang hidup pada masyarakat (living law) dan dimanfaatkan sebesar-besarnya demi kepentingan masyarakat itu sendiri.

Dalam sistem pemidanaan, teori ini berkembang ke arah kombinasi teori, yaitu antara teori pembalasan (absolute theory) dengan teori tujuan (relative theory) yang selanjutnya memunculkan open system theory dengan tujuan law and other. Setiap orang yang melakukan kejahatan diberikan pembalasan yang setimpal dengan tujuan membuat jera pelaku tersebut dan sekaligus menakutinakuti masyarakat. Sepintas teori gabungan ini seolah-olah telah memenuhi hasrat keadilan dan nilai ketertiban masyarakat, namun teori ini jika hendak dijalankan dengan baik dan benar, ia harus disesuaikan dengan sistem peradilan pidana yang dijalankan. Sepanjang sistem peradilan pidananya masih berkutat dengan model administratif-birokrasi yang bersifat normatif, maka sangat sulit untuk melaksanakan teori gabungan. Karena nilai keadilan yang dimunculkan oleh model peradilan pidana yang adminstratif-birokrasi itu hanya memenuhi keadilan formal, sekedar pemenuhan perundangundangan, akibatnya law enforcement tidak sesuai dengan tujuan sebenarnya.

Jurnal Komunikasi Hukum

\section{Urgensi Perubahan Sistem Pemidanaan}

Menyikapi perkembangan sistem pemidanaan sebagaimana yang tergambar di atas, semua sistem yang dianut tetap dalam pola pemberian hukuman yang mengarah pada fisik pelaku kejahatan. Dapat dikatakan seluruh sistem tersebut mengedepankan sarana penghukuman fisik untuk memperolah capaian atau tujuan dari pemidanaan, yaitu memberikan rasa jera dan menakut-nakuti masyarakat.

Dalam pandangan para ahli hukum pidana, hukuman atau sering disebut dengan pidana diartikan sebagai suatu penderitaan (infliction) yang sengaja diberikan kepada setiap orang yang telah terbukti melakukan suatu tindak pidana. Fitzgerald mengatakan: "punishment is the authoritative infliction of suffering for an offence".Sir Rupert Cross juga mengatakan: "punishment means: the infliction of pain by the state on someone who has been convicted of an offence" (Muladi dan Barda Nawawi Arief,1992:2-3)

Dengan demikian jelas pidana (punishment) merupakan penderitaan yang sengaja dilekatkan pada pelaku kejahatan, terlepas dari apapun tujuan pemidanaan itu sendiri. Para ahli hukum pidana mekonstruksikan pidana sebagai suatu keharusan yang dilakukan dalam rangka menemukan keadilan.

Dalam keilmuan hukum pidana termasuk dalam dogmatik hukum pidana, selalu menempatkan pidana sebagai dewa pemberi keadilan. Tidak ada cara lain selain pidana yang dapat memberikan keadilan, sehingga seluruh ketentuan perundang- 
undangan yang mengatur tentang tindak pidana menempatkan sanksi pidana di dalamnya. Namun demikian, fakta sosial mengatakan perkembangan kejahatan terus meningkat dan pidana yang di tempatkan sebagai sarana untuk mencegah kejahatan ternyata tidak menunjukkan hasil yang diharapkan. Paradigma pemidanaan tampak mandul, terutama ketika berhadapan dengan pelaku-pelaku tertentu.

Di tengah-tengah usaha penanggulangan terhadap kejahatan dengan penggunaan sarana penal yang memunculkan rasa pesimistis dari pemikir abolisionisme yang sangat menentang penggunaan sarana penal (pidana) dalam menanggulangi kejahatan. Beberapa pemikir abolisionisme seperti Fillipo Gramatica dan Olof Kinberg melakukan gerakan revolusioner terhadap pandangan pemidanaan yang menekankan pada penderitaan terhadap fisik, yaitu menggunakan sarana pidana (punishment).

Ide penghapusan pidana yang paling ekstrim muncul dari Fillipo Gramatica pada tahun 1947 dalam tulisannya yang berjudul La lotta contra la pena (the fights against punishment) menegaskan: "hukum perlindungan sosial harus menggantikan hukum pidana yang ada sekarang" (Dalam Romli Atmasasmita,1996:19). Tujuan utama dari hukum perlindungan sosial adalah mengintegrasikan individu ke dalam tertib sosial dan bukan pemidanaan terhadap perbuatannya.

Kemudian Olof Kinberg juga memberikan pandangan sebagai tokoh abolisionis dalam bukunya $L e$ droit de punir pada tahun 1948 yang mengatakan: kejahatan pada umumnya merupakan perwujudan ketidaknormalan atau ketidakmatangan si pelanggar (the expression of an offenders's abnormality or immaturity) yang lebih memerlukan tindakan perawatan (treatment) daripada pidana (Dalam Romli Atmasasmita, 1996:20)

Pola pemikiran kaum abolisionis ini sangat dipengaruhi oleh paham determinisme yang menyatakan bahwa orang tidak mempunyai kehendak yang bebas dalam melakukan perbuatan, karena dipengaruhi oleh watak pribadinya, faktor-faktor biologis dan faktor lingkungan kemasyarakatannya. Dengan demikian sebenarnya kejahatan merupakan manisfestasi dari keadaan jiwa seseorang yang abnormal, oleh karena itu pelaku kejahatan tidak dapat dipersalahkan atas perbuatannya dan tidak dapat dikenakan pidana. Ketidaknormalan organik dan mental tidak dapat diperbaiki dengan pidana, tetapi diperlukan tindakan (treatment).

Menurut penulis pola pemikiran abolisionis ini mengacu pada faktor eksternal dari pelaku kejahatan. Orang melakukan kejahatan tidak saja disebabkan oleh masalah internal dirinya, tetapi lebih banyak disebabkan oleh masalah eksternal yang kemudian mempengaruhi ke dalam dirinya yang disebabkan psikologis yang tidak sehat. Sehingga yang diperlukan bukan pidana (punishment) terhadap dirinya, melainkan tindakan (treatment) perbaikan pada faktor psikologisnya.

Penjatuhan pidana melalui proses peradilan pidana justru memperburuk keadaan sosial, karena 
ISSN : 2356-4164

bagaimanapun pelaku sebagai individu yang patut mendapat perlindungan hukum, bukan mendapatkan penderitaan. Selain itu, dalam mekanisme kerja sistem peradilan pidana pelaku tidak pernah diikutsertakan dalam penentuan tujuan akhir dari pemberian pidana terhadap dirinya, bahkan para korban kejahatanpun tidak pernah mendapat manfaat dari hasil akhir suatu peradilan pidana.

Oleh karena itu sudah selayaknya dilakukan perubahan paradigma sistem peradilan pidana dari model penderitaan fisik ke model perbaikan/pembinaan psikis. Untuk itu diperlukan pemikiran baru yang holistik dan bersifat revolusioner terhadap sistem peradilan pidana, sehingga salah satu jalan menuju welfare state akan tercapai. Salah satu jalannya adalah dengan perubahan paradigma sistem pemidanaan dari model penyiksaan fisik ke arah pembinaan psikis pelaku tindak pidana.

Berkaitan dengan model pemidanaan dari yang bersifat fisik menuju model pemidanaan yang bersifat psikis ini, maka yang pertama harus dilakukan adalah perubahan model sistem peradilan pidana dari yang bersifat retributive justice ke arah peradilan yang bersifat restorative justice. Mengapa demikian? Karena jika dipertahankan dengan model retributive justice yang mengandalkan cara-cara lama yang bersifat administrative birokratis, sulit bagi kita untuk melakukan perubahan tersebut. Jadi landasannya harus restorative justice.

Untuk mengetahui perbandingan antara kedua model peradilan tersebut, berikut penulis sampaikan pandangan Howard Zehr (1990:21) tentang perbandingan kedua sistem peradilan tersebut :

\begin{tabular}{|c|c|}
\hline Retributive Justice & Restorative Justice \\
\hline $\begin{array}{l}\text { 1. Crime defined as violation of the } \\
\text { state }\end{array}$ & $\begin{array}{l}\text { 1. Crime defined as violation of one } \\
\text { person by another }\end{array}$ \\
\hline $\begin{array}{l}\text { 2. Focus on establishing blame, on } \\
\text { guilt, on past }\end{array}$ & $\begin{array}{l}\text { 2. Focus on problem solving, on liabilities } \\
\text { and obligations, on future (what } \\
\text { should be done) }\end{array}$ \\
\hline $\begin{array}{l}\text { 3. Adversarial relationship and } \\
\text { process normative }\end{array}$ & 3. Dialogue \& negotiation normative \\
\hline $\begin{array}{l}\text { 4. Imposition of pain to punish and } \\
\text { deter/prevent }\end{array}$ & $\begin{array}{l}\text { 4. Restitution as a means of restoring } \\
\text { both parties goal of } \\
\text { reconciliation/restoration }\end{array}$ \\
\hline $\begin{array}{l}\text { 5. Justice defined by intent \& } \\
\text { process: right rules }\end{array}$ & $\begin{array}{l}\text { 5. Justice defined as right relationship } \\
\text { and outcomes }\end{array}$ \\
\hline $\begin{array}{l}\text { 6. Interpersonal, confilictual nature } \\
\text { of crime obscured, repressed; } \\
\text { conflict seen as individual vs the } \\
\text { state }\end{array}$ & $\begin{array}{l}\text { 6. Crime recognized as interpersonal } \\
\text { conflict; value of conflict is recognized }\end{array}$ \\
\hline $\begin{array}{l}\text { 7. One social injury replaced by } \\
\text { another }\end{array}$ & 7. Focus on repair of social injury \\
\hline
\end{tabular}


ISSN : 2356-4164

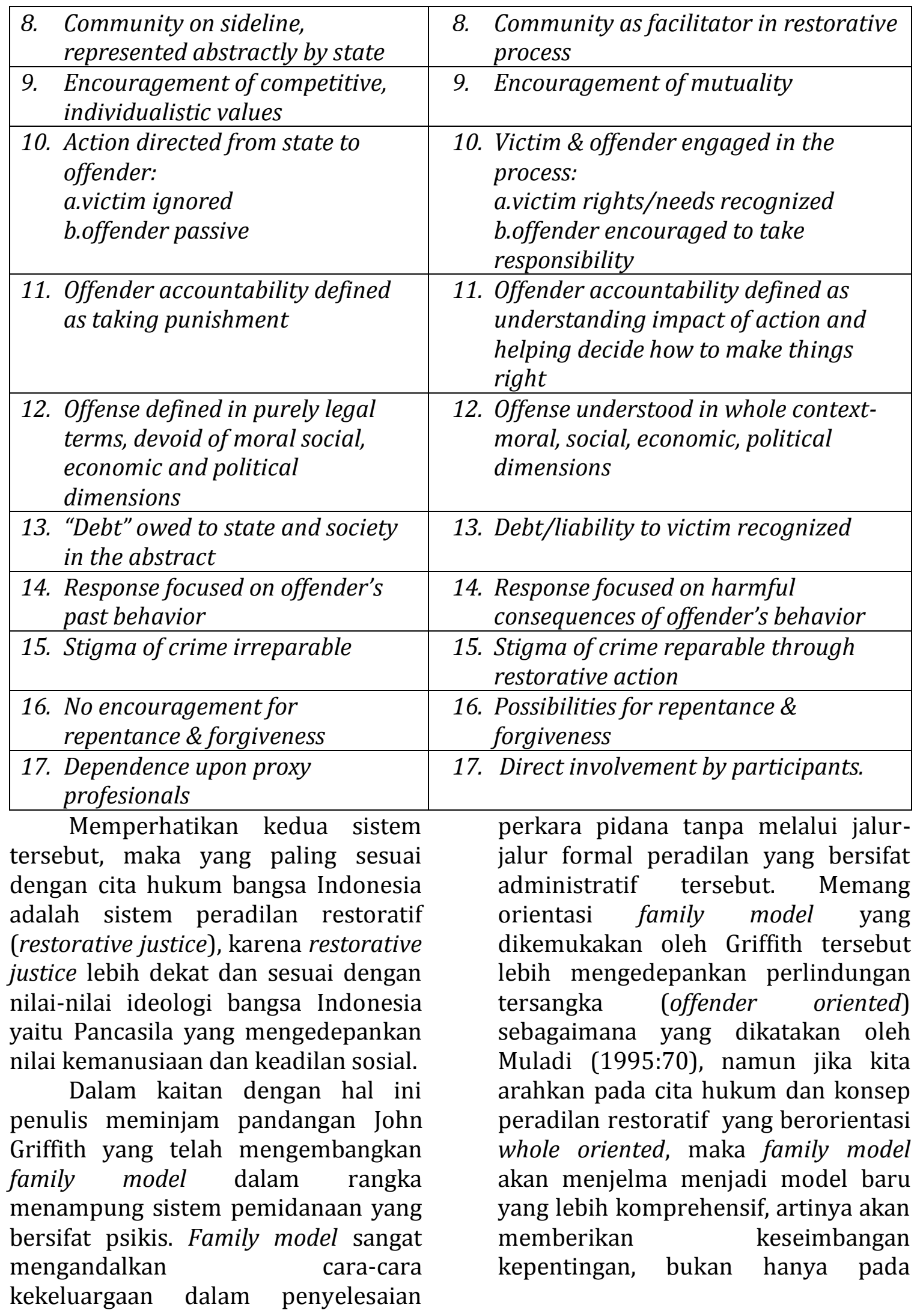


terdakwa dan korban, tetapi juga terhadap masyarakat dan negara.

Bentuk-bentuk sanksi yang mungkin ditawarkan dalam paradigma baru sistem pemidanaan adalah dapat berupa sanksi pemberian rasa malu yang bersumber dari shame culture yang dimiliki oleh bangsa Indonesia, misalnya saja model permaluan dalam masyarakat bugis (sirih). Atau meminjam dari sistem hukum perdata, yaitu penekanan pada ganti rugi atas kerugian yang telah ditimbulkan oleh pelaku ataupun yang lebih berat adalah pengusiran atau pembuangan pelaku dari masyarakat setempat atau dapat pula meminjam model-model treatment yang terdapat dalam hukum ketatanegaraan.

Untuk pemikiran ini menurut penulis perlu dilakukan penelitian mendalam tentang sistem sanksi yang menggantikan sanksi fisik ke model pembinaan psikis.

\section{Simpulan}

Keseimbangan antara nilai kepastian hukum dan ketertiban sosial harus segera diwujudkan dalam suatu perubahan paradigma baru. Hukum diciptakan bukan untuk memberikan penderitaan pada manusia, melainkan diciptakan untuk kebaikan/ kemaslahatan umat manusia.

Pergantian sistem sanksi dari yang bersifat fisik ke model pembinaan psikis harus diikuti perubahan sistem peradilan pidana yang sesuai dengan cita hukum bangsa Indonesia, hal ini penting mengingat setiap hukum yang diciptakan harus sesuai dengan ideologi bangsa sebagai pedoman yang harus diperhatikan, karena idealnya model peradilan pidana beserta dengan sistem sanksinya harus sesuai dengan ideologi negara.

Untuk itu pula penulis merekomendasikan untuk dilakukan penelitian-penelitian terhadap sistem peradilan pidana yang ada dalam rangka mengembangkan atau membentuk sistem peradilan yang baru agar dapat menampung sistem sanksi yang bersifat non fisik (psikis) tersebut.

\section{Daftar Pustaka}

Barda Nawawi Arief, 2010, Kebijakan Legislatif dalam Penanggulangan Kejahatan dengan Pidana Penjara, Genta, Yogyakarta.

Barda Nawawi Arief, 1996, Bunga Rampai Kebijakan Hukum Pidana, Citra Aditya Bakti, Bandung.

Hoaward Zehr, 1990, Changing Lenses: A New Focus For Crime and Justice, Herald Press, Scotdale, PA.

Jujun S. Suriasumantri, 2003, Filsafat Ilmu Sebuah Pengantar Populer, Pustaka Sinar Harapan, Jakarta.

Mardjono Reksodiputro, 1997, Hak Asasi Manusia Dalam Sistem Peradilan Pidana, Pusat Pelayanan Keadilan dan Pengabdian Hukum Universitas Indonesia, Jakarta.

Mochtar Kusumaatmadja,2006, Konsep-konsep Hukum Dalam Pembangunan, Alumni, Bandung. Muladi dan Barda Nawawi Arief, 1992, Teori-Teori dan Kebijakan Pidana, Alumni, Bandung.

Muladi, 1995, Kapita Selekta Sistem Peradilan Pidana, Badan Penerbit Universitas Diponegoro, Semarang. 
Romli Atmasasmita, 1996, Sistem

Peradilan Pidana di Indonesia, Putra Bardin, Jakarta.

Romli Atmasasmita, 1996, Sistem

Peradilan Pidana Perspektif

Eksistensialisme dan

Abolisionisme, Bina Cipta,

Bandung.

Saparinah Sadli, 1976, Persepsi Sosial

Mengenai Perilaku Menyimpang, Bulan Bintang, Jakarta.

Sudarto, 1977, Hukum dan Hukum Pidana, Alumni, Bandung.

Sudjono Dirdjosisworo, 1996, Sosiologi Hukum: studi tentang perubahan hukum dan sosial, RadjaGrafindo Persada, Jakarta.

Soerjono Soekanto, 1986, Pengantar Penelitian Hukum, UI Press, Jakarta.

W. Friedmann, 1996, Legal Theory (Terjemahan Teori dan Filsafat Hukum), RajaGrafindo Persada, Jakarta.

Zainuddin Ali, 2009, Filsafat Hukum, Sinar Grafika, Jakarta. 